\title{
Rozwód Georges'a du Roy w Bel-Ami Guy de Maupassanta w kontekście zmian we francuskim ustawodawstwie rozwodowym drugiej połowy XIX wieku
}

\author{
Georges du Roy's Divorce in Guy de Maupassant Novel Bel-Ami in the Context of French \\ Divorce Legislation Changes in the Second Half of the $19^{\text {th }}$ Century
}

\begin{abstract}
Fitting into the current law and literature movement, the article focuses on the literary depiction of changes within divorce proceedings in nineteenth-century France based on Guy de Maupassant's novel Bel-Ami. Written in 1885, the book depicts, in a highly realistic manner, fault-based divorce proceedings at the time of its creation. In the introduction, I briefly touch upon the evolution of the French divorce proceedings throughout the eighteenth and nineteenth centuries, and its final outcome: the legalisation of a dissolution of marriage in 1884 . The article attempts to answer the question how that revolutionary change of the divorce law influenced the novel's content and how Guy de Maupassant depicted the dissolution of marriage in his work, and to verify if this depiction reflects legal reality.
\end{abstract}

Keywords: Bel-Ami, Guy de Maupassant, law and literature, divorce in literature

\begin{abstract}
Abstrakt: Wpisując się w aktualny ruch prawniczy i literacki, artykuł skupia się na literackim przedstawieniu zmian w postępowaniu rozwodowym w dziewiętnastowiecznej Francji na podstawie powieści Guy de Maupassanta Bel-Ami. Napisana w 1885 roku książka w bardzo realistyczny sposób przedstawia proces rozwodowy oparty na winie, tak jak wyglądał on w momencie jej powstania. We wstępie pokrótce omawiam ewolucję francuskiego postępowania rozwodowego w XVIII i XIX wieku i jego końcowy rezultat: legalizację rozwodu wprowadzoną w 1884 roku. Artykuł podejmuje próbę odpowiedzi na pytanie, ta rewolucyjna zmiana prawa rozwodowego wpłynęła na treść powieści i sposób, w jaki Guy de Maupassant przedstawił zakończenie małżeństwa, a także próbę zweryfikowania, czy ten obraz odzwierciedla ówczesną rzeczywistość prawną.
\end{abstract}

Słowa kluczowe: Bel-Ami, Guy de Maupassant, prawo i literatura, rozwód w literaturze 


\section{Wstęp}

Ewolucję prawa należy postrzegać nie tylko w kontekście zmian ustawodawczych, ale również jako świadectwo ewolucji poglądów i dowód zmian zachodzących w moralności ludzkiej. Jak zauważa Julie Ringelheim, zmiany społeczne i prawne warunkują się wzajemnie, do tego stopnia, że prawo samo w sobie również może być postrzegane jako odrębne zjawisko społeczne ${ }^{1}$. Badania nad rozwojem prawa nie mogą być zatem oderwane od badań nad zmianami społecznymi. Badań tych nie można również oddzielać od przemian zachodzących w kulturze, której ewolucji prawo jest nie tylko świadkiem, ale również często motorem bądź odzwierciedleniem ${ }^{2}$. $Z$ drugiej strony należy pamiętać, że rozmaite teksty kultury także komentują i oceniają zmiany zachodzące w prawie i literaturę można w związku z tym interpretować również w odniesieniu do prawa obowiązującego w czasach, w których dane dzieło powstawało. Przełom XVIII i XIX wieku, będący tak ważnym momentem z punktu widzenia rozwoju francuskiego ustawodawstwa, czasem rewolucji, wielkich zmian w prawie i ujednolicenia prawa cywilnego, stanowił także czas przemian kulturowych, odejścia od moralności ancien régime i kształtowania społeczeństwa liberalnego.

Szczególnie interesującym polem do badań zachodzących wówczas zmian jest instytucja małżeństwa i problem jego trwałości, które to kwestie stały się przedmiotem debat zarówno prawnych, jak i społecznych oraz literackich. Niniejsze opracowanie ma na celu zastanowienie się, w jaki sposób zmiany zachodzące wówczas w prawie mogły wpływać na rozwój kultury, a w szczególności na kierunek rozwoju literatury pięknej. Na samym wstępie krótko omówiona zostanie ewolucja francuskiego prawa rozwodowego, by następnie móc zastanowić się nad tym, w jaki sposób zmiany te wpłynęły na teksty literackie powstające w tym okresie na przykładzie powieści Bel-Ami autorstwa Guy de Maupassanta.

\section{Rozwój ustawodawstwa rozwodowego we Francji - kontekst prawny i historyczny zmian}

Jako moment, kiedy po raz pierwszy podano w wątpliwość obowiązującą przez wieki chrześcijańską zasadę nierozerwalności małżeństwa, należy wskazać rewolucję francuską. Już w konstytucji z 1791 roku wprowadzono przełomową zmianę uznającą małżeństwo za umowę cywilną, a nie, jak to było dotychczas, za sakrament ${ }^{3}$. Niezwykle liberalna ustawa, uchwalona zaledwie rok później, bo 20 września 1792 roku, wprowadziła łatwą do spełnienia przesłankę rozwodu,

1 J. Ringelheim, Droit, contexte et changement social, „Revue interdisciplinaire d'études juridiques" 2013, 1/70, s. 157-158. Z tego założenia wychodzą również inne badania prowadzone w obrębie kierunku nazywanego socjologią prawa.

2 Por. L. Rosen, Law as Culture. An Invitation, Princeton 2006.

3 Y. Bruley, Mariage et famille sous Napoléon : le droit entre religion et laïcité, „Napoleonica. La Revue" 2012, n 14, s. 115. 
jaką jest niezgodność charakterów ${ }^{4}$. Rok później zadecydowano o utrudnieniu procedury, która okazała się w praktyce zbyt dostępna, a przez to skutkowała rosnącą liczbą rozwodów ${ }^{5}$. Zaburzało to stabilność życia rodzinnego i w dalszej perspektywie destabilizowało całe życie społeczne. Choć wciąż istniały w stosunku do instytucji rozwodu wątpliwości natury religijnej, to nikt nie podawał już w wątpliwość jego prawnej dopuszczalności.

Podczas prac redakcyjnych nad francuskim kodeksem cywilnym (Code civil), który miał w zamierzeniu być aktem prawnym obowiązującym przez długie lata, a zatem w jak najpełniejszy sposób regulować stosunki społeczne, legislator stanął przed trudnym wyzwaniem znalezienia rozwiązania, które z jednej strony umożliwiłoby zakończenie małżeństwa poprzez rozwód (na co nalegał podobno bardzo sam cesarz, który prawdopodobnie rozważał już wówczas rozwód z Józefiną ${ }^{6}$, a $z$ drugiej utrudniłoby podejmowanie zbyt pochopnych decyzji zarówno w kwestii zawarcia, jak i zakończenia małżeństwa ${ }^{7}$. Ostatecznie zdecydowano się na utrzymanie instytucji rozwodu za porozumieniem stron, $\mathrm{z}$ winy jednego $\mathrm{z}$ małżonków (w przypadku zdrady czy też poważnej krzywdy wyrządzonej współmałżonkowi ${ }^{8}$ ), a także w razie skazania jednego ze współmałżonków na „hańbiącą karę" (peine infamante), nie dopuszczając jednak przesłanki niezgodności charakterów (wszystkie przesłanki rozwodu wymienione zostały w rozdziale I tytułu VI kodeksu cywilnego). Należy również nadmienić, że kodeks cywilny z 1804 roku w znacznej mierze upośledzał pozycję kobiety w procedurze rozwodowej, umożliwiając jej wniesienie pozwu z powodu zdrady jedynie w sytuacji, w której mąż wprowadził konkubinę do wspólnego domu małżonków (art. 230)9.

W czasach restauracji, w związku ze wzrostem znaczenia Kościoła katolickiego, ponownie zaczęły przeważać argumenty natury religijnej. Doprowadziły one do uchwalenia 8 maja 1816 roku tzw. ustawy Bonalda (loi Bonald ${ }^{10}$, znoszącej całkowicie możliwość zakończenia małżeństwa przez rozwód, a dopuszczającej

${ }^{4}$ J. Carbonnier, Droit civil. Introduction, les personnes, La famille, l'enfant, le couple, Paris 2004, s. 1277.

5 J.P. Sardon, L'évolution du divorce en France, ,Population” 1996, 51e année, n³ 3, s. 718.

${ }^{6}$ Ibid.

${ }^{7} \mathrm{~W}$ pierwszych latach po dopuszczeniu możliwości rozwodu liczba złożonych pozwów była istotnie ogromna, co jednak zapewne związane było z faktem, że wcześniej nikt nie mógł takiego pozwu wnieść, por. R.G. Phillips, Le divorce en France à la fin du XVIII siècle, „Annales. Économies, Sociétés, Civilisations" 1979, 34/2, s. 385-398.

${ }^{8}$ Artykuł 231 kodeksu cywilnego dopuszczał rozwód w przypadku „nadużycia, znęcania się i poważnej krzywdy", nie doprecyzowywał jednak, o jakie przypadki chodzi i kwestia ta była pozostawiona orzekającym sądom, które za każdym razem musiały uzasadnić, o który zarzut konkretnie chodzi. Więcej na temat problemów orzeczniczych z tym związanych zob: B.D. Hollender, La notion de fait injurieux dans le divorce et la séparation de corps au XIXe siècle, „Revue historique de droit français et étranger" 2012, 90/3, s. 329-378.

${ }^{9}$ Która to sytuacja nie była rzadka, zważając na częstotliwość związków ze służącymi, a także liczne pozwy rozwodowe, które związane były z brakiem akceptacji przez żonę kochanki mieszkającej we wspólnym domu (por. R.G. Phillips, op. cit., s. 391).

${ }_{10}$ Więcej o kontekście uchwalenia ustawy: F.B. de Balanda, Louis de Bonald et la question $d u$ divorce de la rédaction du code civil à la loi du 8 mai 1816, „Histoire, économie \& société” 2017, $\mathrm{n}^{\circ} 3$, s. $82-84$. 
jedynie separację małżonków. Nowa ustawa przywróciła więc w praktyce stan prawny sprzed czasów rewolucji francuskiej.

Dyskusja na temat przywrócenia możliwości rozwodu nie zakończyła się jednak i w pierwszej połowie XIX wieku do głosu zaczęły dochodzić znów prądy liberalne postulujące przywrócenie instytucji rozwodu. Podjęto kilka prób zmiany obowiązującego prawa małżeńskiego, ale zakończyły się one sukcesem dopiero 27 lipca 1884 roku, kiedy uchwalona została tzw. ustawa Naqueta (loi Naquet). Dopuściła ona możliwość rozwodu w większości przypadków wymienionych w ustawie z 1804 roku, a więc w razie przewinienia jednego z małżonków wobec drugiego, skazania na hańbiącą karę czy zdrady. Nie powróciła ona jednak do wcześniejszej liberalnej możliwości rozwiązania małżeństwa za porozumieniem stron, czyniąc tym samym z instytucji rozwodu jedynie środek represji za przewinienie jednego z małżonków ${ }^{11}$, gdyż wszystkie przesłanki rozwodu wiązały się ze stwierdzeniem winy. Należy podkreślić jednocześnie, że nowa ustawa była dużo korzystniejsza dla kobiet, gdyż dodany w niej został artykuł 230, stanowiący, że małżonka może zawnioskować o rozwód z powodu zdrady męża w każdej sytuacji, nie tylko wówczas, gdy ten wprowadzi do ich wspólnego domu konkubinę.

Już na podstawie tego krótkiego rysu historycznego widać, że ewolucja francuskiego prawa rodzinnego na przełomie XVIII i XIX wieku była niezwykle dynamiczna, zaś zdaniem wielu badaczy nowelizacje code civil w tym zakresie były jednymi z najważniejszych, jakich dokonano we francuskim prawie cywilnym w XIX wieku ${ }^{12}$. W ciągu zaledwie kilku dziesięcioleci do głosu dochodziły wzajemnie wykluczające się poglądy, które sprawiły, że tworzone wówczas prawo proponowało naprzemiennie skrajnie różne rozwiązania.

\section{Związek między zmianami prawnymi a powstającymi w ich czasie tekstami - założenia badań w nurcie law and literature}

Jak już wcześniej podkreślono, dyskusji na temat zasadności instytucji rozwodu na przełomie XVIII i XIX wieku nie należy postrzegać wyłącznie poprzez perspektywę argumentów prawnych oraz rezultatów prac legislacyjnych. Zdaniem Stéphane Gougelmanna i Anne Verjus, aby zrozumieć małżeństwo w dziewiętnastowiecznej Francji, należy przyjrzeć się ustawodawstwu, które regulowało wówczas tę instytucję, nieustannie jednak pamiętając, że normy nie mówią wiele o praktyce ich stosowania ${ }^{13}$.

Zagadnienie możliwości zakończenia małżeństwa przez rozwód interesowało bowiem nie tylko legislatora, ale przede wszystkim zwykłych ludzi, na których życie i szczęście bezpośrednio wpływały zmiany w prawie. Wątek trwałości małżeństwa pojawiał się zatem także w tekstach niezwiązanych bezpośrednio z prawem. W czasach, kiedy rozwód nie był możliwy, wydawana od roku 1825 „Ga-

11 J.P. Sardon, op. cit., s. 718.

12 Por. S. Gougelmann, A. Verjus, Introduction [w:] Écrire le mariage en France au XIXe siècle, dir. S. Gougelmann, A. Verjus, Saint-Étienne 2016, s. 13.

13 Ibid., s. 16. 
zette des Tribunaux", będąca w dużej mierze kroniką spraw o podłożu prawnym, które poruszały wówczas opinię publiczną, obfitowała w relacje o zdradach i innych tragicznych skutkach niemożności wyzwolenia się z więzów nieszczęśliwego małżeństwa, a jej adresatami byli zwykli ludzie, nieposiadający wykształcenia prawniczego ${ }^{14}$. Problematyka zdrady i kary wymierzonej niewiernemu małżonkowi była spotykana także na łamach innych popularnych wówczas gazet sądowych $^{15}$.

Wydaje się także, że w badaniach nad postrzeganiem instytucji małżeństwa nie można pominąć tekstów literackich. Gougelmann i Verjus zauważają, że literatura już od czasów restauracji miała tendencję do przedstawiania małżeństw z rozsądku jako nudnych, przygnębiających, a czasem wręcz zmuszających do ponoszenia ofiar. W celu ukazania ciągłości tej tendencji w późniejszym czasie badacze wskazują między innymi na twórczość Honoré de Balzaca i George Sand ${ }^{16}$. Paul Kompanietz w swoim opracowaniu również podkreśla rolę, jaką dzieła literackie odgrywały od czasów Oświecenia w debacie toczącej się wokół tematyki małżeństwa i instytucji rozwodu, będąc, w przeciwieństwie do dzieł prawniczych, tekstami, które zdolne były „ucieleśnić doświadczenia konkretnej jednostki" ${ }^{\prime 1}$.

Zgodnie $\mathrm{z}$ metodologią wypracowaną $\mathrm{w}$ nurcie law and literature $\mathrm{w}$ badaniach nad rozwojem prawa pomocna może być literatura, która wiele mówi o pojmowaniu instytucji ustawowych przez ludzi żyjących w danej rzeczywistości prawnej. Tego typu badania pozwalają na przyjęcie szerszej perspektywy, odrywając studia nad ewolucją prawa od analizy ustaw i ukazując, w jaki sposób zmiany legislacyjne rezonowały w społeczeństwie. Co więcej, usytuowanie tekstu literackiego w kontekście prawnym pozwala czasem lepiej zrozumieć treść utworu, a w szczególności wybory moralne podejmowane przez bohaterów, które są często przedmiotem analizy literaturoznawczej ${ }^{18}$. Zdaniem Christiana Bieta prawo może niekiedy stać się wręcz czynnikiem rządzącym całym tekstem literackim ${ }^{19}$. Pochylenie się nad tekstami literackimi pozwala zatem na przyjrzenie się, w jaki sposób zmiany w prawie były postrzegane przez ludzi niekoniecznie z nim związanych, a jednak bezpośrednio zainteresowanych kierunkami jego rozwoju. Wydaje się więc, że interesującym jest przebadanie, w jaki sposób zmiana we francuskim prawie rozwodowym po 1884 roku została ukazana w literaturze.

${ }^{14}$ Więcej na ten temat: A. Durepaire, Chronique de fait divers et grandes affaires judiciaires : des différents discours sur le désordre des conduites dans la Gazette des tribunaux à la fin $d u X I X^{e}$ siècle, „Les cahiers du journalisme” 2007, 17, s. 232.

${ }^{15}$ Por. „Le palais de justice. Journal pittoresque des Tribunaux”, 25.02.1834, s. 1.

${ }^{16}$ S. Gougelmann, A. Verjus, op. cit., s. 21.

17 P. Kompanietz, Le divorce en débat dans le roman du tournant des Lumières [w:] Écrire le mariage en France..., op. cit., s. 38.

${ }^{18}$ A. Bańczyk, Literacki obraz przysięgi oczyszczajacej Izoldy a praktyka stosowania ordaliów w średniowieczu, „Prace Naukowe Akademii im. Jana Długosza w Częstochowie. Studia Neofilologiczne" 2018, z. XIV, s. 59.

${ }^{19}$ C. Biet, L'empire du droit, les jeux de la littérature, „Europe” 2002, 876, s. 11. 


\section{Kontekst historyczno-prawny powstania powieści Bel-Ami Guy de Maupassanta}

To właśnie w atmosferze zmian z tego czasu napisana została powieść Bel-Ami ${ }^{20}$ autorstwa Guy de Maupassanta, która również w pewien sposób zabiera głos w dyskusji na temat prawa rozwodowego. Na podkreślenie zasługuje fakt, że autor ten w 1869 roku zapisał się na wydział prawa w Paryżu ${ }^{21}$ i choć nigdy nie ukończył tego kierunku, gdyż jego studia przerwała w 1870 roku wojna ${ }^{22}$, to mógł on zachować pewną dozę świadomości prawnej, wykształconą w czasie studiów, i umiejętność analizy tekstów prawnych. Interesujące jest także, że powieść Bel-Ami powstała zaledwie rok po zmianach legislacyjnych nowelizujących prawo rozwodowe, bo już w 1885 roku. Początkowo ukazywała się ona jako powieść w odcinkach, drukowana była na łamach czasopisma „Gil-Blas” od poniedziałku 6 kwietnia 1885 roku, a dopiero potem wydano ją drukiem jako całość.

W zapowiedzi nowego cyklu, która wydrukowana została na pierwszej stronie „Gil-Blas” z 5 kwietnia 1885 roku, można przeczytać, że Maupassant ma do zaproponowania swoim czytelnikom historię ,zręcznego i pozbawionego skrupułów młodzieńca, jednego z tych przyjemnych i silnych ludzi, którzy obdarzeni są wdziękiem i zdolnością uwodzenia, cechami niezbędnymi ambitnym" oraz że „ta niezwykle wartka powieść opisuje sylwetki uroczych i prawdziwych Paryżan zaobserwowane w rzeczywistym życiu"23 (tłumaczenie i podkreślenie własne). Już na podstawie tej krótkiej zapowiedzi można zatem wywnioskować, że z założenia mamy do czynienia $\mathrm{z}$ powieścią wpisującą się $\mathrm{w}$ nurt realizmu, a zatem mającą w jak najpełniejszy sposób oddać ówczesną rzeczywistość, także tę prawną. Zdaniem Rogera Bismuta powieść tę można uznać wręcz za sumę jej czasów, jako że w pełny i przekrojowy sposób prezentuje ona problemy pojawiające się w ówczesnym społeczeństwie ${ }^{24}$.

Powieśćc ${ }^{25}$ opisuje losy parweniusza Georges'a du Roy de Cantel (początkowo noszącego nazwisko Duroy, którego pisownia będzie ewoluowała wraz z postępującym awansem społecznym bohatera ${ }^{26}$ ), który wspina się po szczeblach kariery dzięki kolejnym związkom z kolejnymi wpływowymi kobietami. Dążąc do zostania wpływowym dziennikarzem, Georges korzysta z pomocy inteligentnej Madeleine de Forestier, żony jednego z pracowników poczytnej gazety. Kiedy jej mąż Charles umiera, Du Roy przekonuje Madeleine do małżeństwa i wraz

${ }^{20}$ Tytuł ten tłumaczony jest niekiedy na język polski jako Uwodziciel. Obie wersje tytułu wydają się równoważne, jednak wersja oryginalna zdaje się lepiej oddawać ducha powieści i to ona zostanie wykorzystana w niniejszym opracowaniu.

${ }^{21}$ C. Philippe, Maupassant précurseur du mariage moderne [w:] Droit des personnes et de la famille. Mélanges à la mémoire de Danièle Huet-Weiller, Strasbourg 1994, s. 367.

22 H. Bloom, Guy de Maupassant, Philadelphia 2004, s. 15.

23 „Gil-Blas”, 5.04.1885, s. 1.

24 R. Bismut, Quelques problèmes de création littéraire dans «Bel-Ami », „Revue d'Histoire littéraire de la France" 1967, 67/3, s. 577.

25 Wszystkie odwołania do powieści i cytaty na podstawie: G. de Maupassant, Bel-Ami, Paris 1910. Wszystkie fragmenty są tłumaczeniami własnymi autorki opracowania.

${ }^{26}$ Francuskie nazwiska szlacheckie co do zasady zaczynają się m.in. od „de”,„du”, „de la”, „des”. 
z jej ręką uzyskuje ogromne pieniądze i pozycję społeczną swojego poprzednika. Okazuje się jednak, że to wszystko nie wystarcza karierowiczowi i kiedy tylko pojawia się perspektywa związku z młodziutką Suzanne Walter, córką redaktora naczelnego gazety „La Vie française”, który jest też bogatym przedsiębiorcą, bohater postanawia pozbyć się dotychczasowej żony.

Taki kierunek rozwoju fabuły w powieści realistycznej, w dziełach napisanych przed rokiem 1884, mógłby doprowadzić do nieszczęśliwego zakończenia. Rzeczywistość otaczająca Maupassanta, a przez to wykreowanych przez niego bohaterów, stanowi jednak już tę, w której rozwód jest możliwy, co pozwala na wzbogacenie fabuły o nowy, interesujący motyw. Należy zgodzić się z NicolasemWhite'em, który dostrzega, że rozwód w tekście literackim nie tylko rozwiązuje dotychczasowe małżeństwo, ale również może stanowić obietnicę nowego. Tym samym wprowadzenie do fabuły wątku rozwodu przyczynia się do całkowitej zmiany postrzegania czasu trwania miłości ${ }^{27}$. Małżeństwo przestaje już zatem być terminem a quo, , punktem wyjścia, od którego wszystko zaczyna ulegać degeneracji”, którym, zdaniem Gougelmanna i Verjus, było często w literaturze XIX wieku ${ }^{28}$. Nie jest również terminem ad quem, jak w konwencjonalnych opowieściach, gdzie traktowane było jako symbol dobrego życia i pożądanego przez wszystkich zakończenia ${ }^{29}$. W sytuacji, kiedy rozwód jest dopuszczalny, małżeństwo może być jedynie jednym z wielu etapów w życiu bohaterów.

Tak jest również w przypadku powieści Bel-Ami. Georges du Roy postanawia pozbyć się swojej żony całkowicie legalnie, rozpocząć nowy etap życia, a jednocześnie doprowadzić do jak najkorzystniejszego dla siebie rozwodu, który nie pozbawiłby go uzyskanych dzięki pierwszemu małżeństwu środków finansowych. W powieści Guy de Maupassanta został zatem wykorzystany nowy interesujący wątek przeprowadzenia procedury rozwodowej i niezwykłe jest, z jak wielką dbałością o detale prawne prowadzona jest akcja w tym zakresie.

\section{Procedura rozwodowa w powieści Bel-Ami}

Z przesłanek rozwodu, przewidzianych przez prawo w momencie powstawania Bel-Ami, w powieści wykorzystana została przesłanka zdrady małżonka. Jest ona bez wątpienia najprostszą do wplecenia w fabułę, a co istotne, możliwość dokonania zdrady odpowiada również osobowości Madeleine stworzonej przez pisarza, bowiem kobieta ta od pierwszych stron powieści kreowana jest na bohaterkę niezależną i niezważającą na konwenanse, będącą jednoczesnym ucieleśnieniem prowokacji i dyskrecji ${ }^{30}$.

Na samym wstępie niezwykle ważne jest podkreślenie, że w dziewiętnastowiecznej Francji zdrada współmałżonka była nie tylko przesłanką rozwodu, ale

${ }^{27}$ N. White, French Divorce Fiction from the Revolution to the First World War, London-New York 2013, s. 3.

${ }^{28}$ S. Gougelmann, A. Verjus, op. cit., s. 27.

${ }^{29}$ Ibid.

${ }^{30}$ R. Bismut, op. cit., s. 588. 
również mogła stać się podstawą odpowiedzialności karnej. Kobiecie, której udowodniono cudzołóstwo, zgodnie z artykułem 337 kodeksu karnego (Code pénal) groziła kara pozbawienia wolności w wymiarze od dwóch miesięcy do dwóch lat. Co więcej, żony, które porzucały swoich mężów, traciły prawo do wspólnego majątku małżonków ${ }^{31}$, który to aspekt wydaje się szczególnie interesujący dla bohatera omawianej powieści, jako że Madeleine wniosła do małżeństwa ogromne pieniądze, a sam Georges nie posiadał znacznego majątku.

Zdaniem Marca Boninchiego zaskakująco duża liczba spraw karnych o zdradę po 1884 roku wynikała w dużej mierze również z tego, że procedura w tego typu sprawach faworyzowała dowód z tzw. stwierdzenia zdrady (constat d'adultère), które raz dokonane, mogło być podstawą postępowania karnego. Zdrada małżonka była wszakże wówczas przestępstwem, zaś artykuł 337 ówczesnego kodeksu karnego przewidywał dla zdradzającej żony karę od dwóch miesięcy do dwóch lat pozbawienia wolności. Wyrok karny umożliwiał zaś następnie szybsze przeprowadzenie procesu cywilnego o rozwód, gdyż nie było konieczne powtórne postępowanie dowodowe w zakresie udowodnionych już okoliczności. Stwierdzona zdrada pozwalała na orzeczenie rozwodu właśnie z jej powodu. Postępowanie karne pozwalało zatem na szybkie stwierdzenie i udowodnienie faktów, które mogły stać się podstawą pozwu cywilnego ${ }^{32}$.

Georges'owi du Roy niewątpliwie zależało na szybkim uzyskaniu rozwodu z powodu perspektywy zawarcia kolejnego, korzystniejszego dla niego, związku małżeńskiego, tym razem z Suzanne Walter. Naiwna dziewczyna, podczas rozmowy we dwoje, obiecuje wprawdzie poczekać na wymarzonego mężczyznę, ale Du Roy zdaje sobie sprawę z realiów życia rodzinnego w czasach, w których przyszło mu żyć, i wie doskonale, że decyzja o ewentualnym zamążpójściu nie należy wyłącznie do niej. Szerzące się w towarzystwie plotki mówią zaś coraz częściej o tym, że państwo Walter planują wydać swoją córkę za markiza de Cazolles. Georges wie, że aby zrealizować swój nowy plan matrymonialny, musi działać szybko i strategicznie. Wydaje się więc, że to presja czasu skłania go do tego, by zaplanować z najmniejszymi detalami całą procedurę mającą prowadzić do stwierdzenia cudzołóstwa Madeleine i do tego, by zaangażować w nią całe rzesze policjantów. Zapewne nie bez znaczenia pozostaje również osoba kochanka pani Du Roy, który jest ministrem, co implikuje, że dowody przeciwko niemu muszą być mocne i nie mogą pozostawiać żadnego pola na domysły, gdyż policja w tego typu sytuacji nie może pozwolić sobie na żaden skandal.

Procedura stwierdzenia cudzołóstwa, która miała stać się podstawą do rozwodu Du Roy, została przez Maupassanta opisana w sposób bardzo szczegółowy. Wydaje się, że precyzja w opisie detali proceduralnych może nie być jedynie skutkiem studenckiego prawniczego epizodu pisarza, lecz również tego, że sprawy związane z cudzołóstwem, jako szczególnie działające na wyobraźnię i rozbudzające emocje, były w czasie pisania powieści niezwykle popularne i często opisywano je w prasie, czego dowodzą liczne artykuły prasowe z gazet

\footnotetext{
${ }^{31}$ S. Desan, Family on Trial in Revolutionary France, Berkeley 2004, s. 304.

${ }^{32}$ M. Boninchi, Vichy et l'ordre moral, Paris 2005, s. 72.
} 
poświęconych problematyce procesowej, takich jak „Gazette des Tribunaux” czy „l'Audience" 33 . Obraz tego, jak powinno wyglądać modelowe stwierdzenie cudzołóstwa, mógł zatem głęboko zakorzenić się w świadomości społecznej, tak więc literackie ukazanie realiów proceduralnych nie sprawiło problemów pisarzowi, który nigdy nie wykonywał zawodu bezpośrednio związanego z praktyką prawniczą, będąc jedynie niższym urzędnikiem w kilku ministerstwach ${ }^{34}$. Niezależnie od powyższych czynników raz jeszcze na podkreślenie zasługuje fakt, że detale prawne w Bel-Ami zostały opisane z niezwykłą dbałością o szczegóły, a Maupassant od samego początku prowadzi akcję w zgodzie z obowiązującą wówczas procedurą.

Autor odzwierciedla zatem wymóg zawarty w artykule 336 francuskiego kodeksu karnego z 1810 roku, który obowiązywał wciąż w roku 1885, zgodnie z którym jedyną osobą uprawnioną do zgłoszenia przestępstwa cudzołóstwa był mąż zdradzającej kobiety. Zastanawiając się nad przyczyną wprowadzenia takiej regulacji, należałoby przyznać rację Joseph-François-Claude Carnotowi, który w swoim komentarzu do kodeksu karnego z 1835 roku wyjaśnia zawężenie kręgu potencjalnych skarżących do męża tym, że to właśnie mąż jest bezpośrednią $\mathrm{i}$ jedyną ofiarą przestępstwa, które uderza jedynie w interes rodziny, a nie w cały porządek społeczny ${ }^{35}$. Należy również podkreślić, że ustawodawca zdawał sobie zapewne sprawę, że w sytuacji, gdy współmałżonek wybaczał przewinienie swojej żonie, popełniona zdrada nie zaburzała w żaden sposób porządku publicznego, pozostając kwestią do rozwiązania wewnątrz rodziny.

Również Georges du Roy wie, że to właśnie do niego należy decyzja o rozpoczęciu postępowania przeciwko Madeleine. Czytelnik dowiaduje się, że bohater od dawna podejrzewa liczne zdrady żony i śledzi jej kroki (s. 515), czeka jednak z ujawnieniem tego na moment, w którym najlepiej będzie mógł zrealizować swój plan, a więc na chwilę, w której będzie pewny co do miejsca i czasu spotkania Madeleine z kochankiem, jak również co do tego, że w razie ewentualnego rozwodu może liczyć na przychylność kolejnej kandydatki na żonę.

Zgodnie z obowiązującymi w czasie powstania dzieła zasadami procedury cudzołóstwo mógł stwierdzić między innymi komisarz policji (commissaire de police). Postać ta, jak zauważają Dominique Kalifa i Pierre Karila-Cohen, zaczyna w XIX wieku coraz częściej pojawiać się we francuskiej literaturze. Zdaniem tych badaczy komisarze nie stają się wówczas jeszcze pełnoprawnymi bohaterami, co nastąpi dopiero w wieku XX wraz z rozwojem literatury detektywistycznej, lecz pozostają postaciami epizodycznymi, pojawiającymi się w miarę potrzeb fabularnych po to, by wykonywać obowiązki, które zostały im przydzielone w realnym

${ }^{33}$ Więcej na temat obrazu cudzołóstwa w prasie można przeczytać w pracy doktorskiej: A. Chabrier, Les genres du prétoire : chronique judiciaire et littérature au XIXe siècle, https://tel. archives-ouvertes.fr/tel-00942986 (dostęp: 28.04.2021).

${ }^{34}$ Więcej na temat urzędniczej kariery Guy de Maupassanta: G. Thuillier, Bureaucratie et bureaucrates en France au XIXe siècle, Genève 1980, s. 3-34.

35 J.-F.-C. Carnot, Commentaire sur le code pénal : contenant : la manière d'en faire une juste application, l'indication des améliorations dont il est susceptible, et des dissertations sur les questions les plus importantes qui peuvent s'y rattacher, vol. 2, Bruxelles 1835, s. 75. 
świecie. Kalifa i Karila-Cohen jako jeden z przykładów przytaczają właśnie procedurę stwierdzenia cudzołóstwa, cytując epizod pochodzący z Kuzynki Bietki (Cousine Bette) Honoré de Balzaca ${ }^{36}$, powieści napisanej jeszcze przed zmianami w prawie rozwodowym, w 1846 roku.

Georges du Roy również kieruje swoje kroki do komisarza policji, który staje się gwarantem właściwego przeprowadzenia procedury. To on orientuje się, które przepisy prawa mają zastosowanie w tej sytuacji i to on krok po kroku przeprowadza bohatera przez poszczególne etapy procedury. Komisarz Guibert de Lorme jest postacią pozornie mało znaczącą, ale to dzięki niemu i jego kompetencjom intryga Georges'a może się udać. Główny bohater niewątpliwie wie, co robi, ale to u komisarza szuka potwierdzenia swoich działań.

Jednym $z$ istotnych elementów jest czas, w jakim dozwolone jest stwierdzenie zdrady. Artykuł 1037 francuskiego kodeksu procedury cywilnej z 1807 roku zakazuje dokonywania jakichkolwiek czynności procesowych pomiędzy szóstą wieczorem a szóstą rano od 1 października do 31 marca oraz pomiędzy dziewiątą wieczorem i czwartą rano w pozostałe miesiące. Godziny te uważane były bowiem za godziny nocne. Również policja, poza przypadkami nagłymi, nie mogła zakłócać spokoju obywateli w tych godzinach i wkraczać do ich mieszkań.

Główny bohater jest świadomy tych ograniczeń, gdyż upewnia się u komisarza: „Ma pan czas do dziewiątej, czyż nie?” (s. 517). Komisarz de Lorme poprawia wówczas Georges'a, parafrazując treść wyżej przytoczonych przepisów, że może dokonać stwierdzenia cudzołóstwa jedynie do godziny dwudziestej pierwszej, jako że jest 5 kwietnia. Dodaje również, że jeszcze niedawno, bo do 31 marca, miałby czas tylko do godziny siódmej (s. 517). Być może zatem to właśnie te ograniczenia czasowe, a nie chęć uzyskania pewności co do przebiegu ewentualnej procedury rozwodowej, sprawiły, że Georges czekał tak długo, zanim złożył doniesienie o podejrzeniu popełnienia przestępstwa. Jeszcze kilka dni wcześniej obowiązywał bowiem swoisty czas zimowy, który dawał możliwość działania jedynie do godziny szóstej po południu, a więc znacznie zawężał katalog okazji, podczas których można było stwierdzić zdradę Madeleine. Podobna dbałość o detale prawne zdaje się świadczyć o dobrej znajomości procedury stwierdzenia cudzołóstwa przez autora tekstu. Jest bowiem mało prawdopodobne, iż fakt, że komisarz policji niemal dokładnie cytuje treść przepisów odnoszących się do procedury stwierdzenia cudzołóstwa, jest przypadkowy.

Kolejnym interesującym aspektem stwierdzenia cudzołóstwa, istotnym dla fabuły analizowanej powieści, jest kwestia przeprowadzenia postępowania dowodowego. Chantal Gleyzes zauważa, że stwierdzić zdradę małżeńską było zawsze niezwykle trudno i nawet w przypadku flagrant délit miano do czynienia ,bardziej z przypuszczeniami niż ze stwierdzeniami" "37. Jednocześnie badaczka zwraca uwagę na orzecznictwo sądów, w którym spotyka się odwołania do dowodów

${ }^{36}$ D. Kalifa, P. Karila-Cohen, Le commissaire de police au XIXe siècle, Paris 2008, s. 15.

${ }^{37}$ Ch. Gleyzes, La femme coupable. Petite histoire de l'épouse adultère au XIXe siècle, Paris 1994, s. 202. 
intymnej relacji znalezionych na miejscu rzekomej zdrady, takich jak stan ubioru pary, stan łóżka, zakłopotanie przyłapanych osób ${ }^{38}$.

Również Maupassant w swojej powieści zwraca wielką uwagę na tego typu detale, odmalowując je z precyzją godną autora piszącego kronikę kryminalną. Na samym początku uwaga czytelnika zostaje zwrócona na lekki strój Madeleine, która ma na sobie jedynie koszulę i halkę, na jej włosy w nieładzie i gołe stopy (s. 520). Pisarz z wielką precyzją opisuje także miejsce popełnienia przestępstwa, a więc sypialnię, w której miało dojść do zdrady, malując obraz pokoju w wielkim nieładzie, zaścielonego ubraniami, zapewne zdejmowanymi uprzednio w pośpiechu: ,sukienka przykrywała krzesło, męskie spodnie przewieszone były przez oparcie fotela. Cztery buty, dwa małe i dwa duże, poniewierały się u podnóża łóżka, przewrócone na bok" (s. 521). Na intymną relację łączącą bohaterkę z ministrem mają wskazywać także, opisane z wszelkimi detalami, ślady zjedzonej we dwoje kolacji i opróżnione do połowy kieliszki po alkoholu (s. 520).

Warto jednak zwrócić uwagę, że sądy orzekające w tamtym czasie w sprawach związanych z cudzołóstwem, aby nie opierać się wyłącznie na domysłach, wypracowały też inną ciekawą linię orzeczniczą. „Gazette des Tribunaux” z dnia 3 września 1890 roku (a więc już po wejściu w życie loi Naquet) przytacza zabawną historię dwóch osób odmiennej płci, które wynajmowały jeden pokój, twierdząc, że robią to wyłącznie z pobudek ekonomicznych i podczas gdy pan Jarreton śpi w łóżku w nocy, wdowa Dupuis czyni to jedynie w dzień, a więc oskarżona o cudzołóstwo para w rzeczywistości zajmuje łóżko na zmianę i nigdy nie śpi w nim razem. Taka argumentacja stron nie przekonała jednak paryskiego sądu i wobec potwierdzenia zeznaniami okoliczności wspólnego zamieszkiwania oboje oskarżeni zostali skazani na 50 franków grzywny. „Gazette” zaś podsumowała wyrok jednym zdaniem: „dwie osoby odmiennej płci zamknięte w pokoju z tylko jednym łóżkiem, to wystarczy, by stwierdzić występek cudzołóstwa" 39 .

Georges, składając doniesienie komisarzowi, zauważa jedynie, że żona spożywa posiłek w „urządzonym mieszkaniu, które wynajęli” („logement garni qu’ils ont loué" - s. 517). Okazuje się, że Du Roy dysponuje szczegółowymi planami tego miejsca i informuje policjantów, że jest w nim jedynie przedpokój i sypialnia (s. 518). Należy zwrócić jednocześnie uwagę na dwuznaczność sformułowania użytego w oryginalnej wersji językowej, bowiem w drugiej połowie XIX wieku logements garnis były często mieszkaniami wynajmowanymi przez kobiety lekkich obyczajów, a także przez osoby pragnące spędzić w nich krótki czas, bez zwracania uwagi sąsiadów. Uchodziły zatem za miejsca umożliwiające znaczne rozluźnienie obyczajów $^{40}$. Policjanci ukazani w powieści zdają sobie zapewne sprawę z dwuznaczności wypowiedzi Georges’a, która znika jednak w polskim tłumaczeniu fragmentu.

Nie dziwi zatem, że całe mieszkanie zostaje przez autora przyrównane do dość obskurnego pokoju hotelowego. Tekst zwraca również uwagę na to, że znajdu-

\footnotetext{
38 Ibid.

39 „Gazette des Tribunaux”, 3.11.1890, s. 836, tłum. własne.

${ }^{40}$ C. Lévy-Vroelant, Un espace ouvert : usages sociaux du logement en ville entre 1830 et 1880 , „Recherches contemporaines” 1996, 3, s. 75.
} 
je się w nim zaledwie jedno łóżko. To właśnie owo łóżko sprawia, że wszelkie wątpliwości co do istnienia intymnych relacji pomiędzy Madeleine i ministrem zostają rozwiane, gdy komisarzowi udaje się wyciągnąc spod kołdry mężczyznę, który za żadne skarby nie chce spod niej wyjść. Okazuje się bowiem wówczas, że minister jest całkiem nagi.

Maupassant zdaje się dostrzegać trudności dowodowe, jakie może napotkać główny bohater. Sam Georges także zdaje sobie sprawę, że niekoniecznie przyłapie swoją żonę na gorącym uczynku. Witając się z komisarzem, oskarża ją zatem jedynie o to, że ,je kolację ze swoim kochankiem" (s. 517). Takie podejrzenie wydaje się jednak zupełnie wystarczać oficerowi policji, który nie widzi żadnych przeszkód, by stało się ono podstawą rozpoczęcia procedury. Fakt, że Du Roy chce jak najbardziej przeciągnąć czynności przygotowawcze i opóźnia wejście do mieszkania aż do za piętnaście dziewiąta, nie wynika $\mathrm{w}$ żadnym razie $\mathrm{z}$ jego niechęci do odkrycia bolesnej prawdy, a raczej z faktu, że bohater wierzy wciąż, iż może jednak zastanie żonę in flagranti, a wtedy jej położenie w trakcie procesu rozwodowego będzie beznadziejne.

Najpewniejszym dowodem jest jednak ten z przyznania się i czytelnik od razu dostrzega, że to do niego dąży komisarz policji. Naciska on początkowo na kochanka, a kiedy ten nie chce składać wyjaśnień, zasłaniając się immunitetem ministra $^{41}$, zwraca się bezpośrednio do Madeleine, która dostrzega, że jej sytuacja jest bez wyjścia i odpowiada: „Nie zaprzeczam. To jest mój kochanek” (s. 527). To w zupełności wystarcza komisarzowi.

Ostatnią rzeczą, jaką należy zrobić, by skutecznie stwierdzić cudzołóstwo, jest spisanie notatki co do przebiegu czynności; zajmują się tym obecni na miejscu policjanci. Czytelnik jest poinformowany, że zwracają oni uwagę także na ,rozkład i stan pomieszczeń" (s. 527). Następnie Du Roy i funkcjonariusze opuszczają mieszkanie. Czytelnik nie wie, jak przebiegało postępowanie przed sądem. Maupassant informuje nas jedynie, że Georges du Roy złożył pozew rozwodowy nazajutrz i że otrzymał rozwód w ciągu trzech miesięcy. Minister spraw zagranicznych został skompromitowany, a dla Du Roy otworzyła się droga do kariery politycznej i nowego małżeństwa.

\section{Podsumowanie}

Zdaniem niektórych badaczy, wśród których znajduje się Catherine Philippe, Maupassant, będąc niechętnym instytucji małżeństwa ${ }^{42}$, nie popierał idei jego nierozwiązywalności i nie wahał się wprowadzać wątku rozwodu do fabuły swoich dzieł ${ }^{43}$. Należy zauważyć, że w przypadku powieści Bel-Ami Maupassant uczynił

${ }^{41}$ Warto zauważyć, iż komisarz dostrzega fakt, że nie można skorzystać z immunitetu w przypadku przyłapania na gorącym uczynku, co jest interesującym punktem do rozważań dotyczących znajomości przez autora zagadnienia immunitetu, jednak wykraczają one poza przedmiot niniejszego opracowania.

${ }^{42}$ C. Philippe, op. cit., s. 368.

43 Ibid., s. 375. 
to bardzo szybko po wprowadzeniu zmian w procedurze rozwodowej, bo zaledwie rok po nowelizacji code civil $\mathrm{w}$ tym zakresie.

Co więcej, w przypadku analizowanej w niniejszym opracowaniu powieści wątek przeprowadzenia procedury rozwodowej staje się niezbędny dla rozwoju akcji, gdyż pomaga głównemu bohaterowi rozpocząć zupełnie nowy etap w życiu. Należy również stwierdzić, że w tym krótkim, a jakże istotnym dla rozwoju akcji powieści epizodzie można dostrzec niezwykłe przywiązanie do detali proceduralnych, które zostały opisane w sposób skrupulatny i konsekwentny. Poszczególne elementy narracji znajdują swoje odzwierciedlenie w konkretnych przepisach prawnych. Maupassant tworzy na kartach swojej powieści niemal wręcz podręcznik postępowania dla tych, którzy chcą udowodnić zdradę swojej współmałżonce. Opis, choć całkowicie fikcyjny, mógłby bez przeszkód stać się punktem wyjścia dla analizy, jakiej dokonaliby ówcześni praktycy prawa, którzy zgodnie z metodą kazusową chcieliby wytłumaczyć zasady funkcjonowania przepisów odnoszących się do rozwodów w praktyce.

Dla autora powieści Bel-Ami, podobnie jak dla wielu innych pisarzy, wśród których można wymienić choćby Honoré de Balzaca ${ }^{44}$, prawo otaczające fikcyjnych bohaterów jest czymś żywym i stale wpływającym na ich życie. Epizod rozwodu Georges'a du Roy de Cantel może być zatem postrzegany również jako ciekawe świadectwo kultury prawnej czasów, w których powstała ta realistyczna powieść. Pokazuje on, jak bardzo zmiany w prawie mogą wpływać na dziedzinę pozornie od niego oddaloną, jaką jest literatura.

\section{Bibliografia (References)}

\section{Źródła}

„Gazette des Tribunaux”, 3.11.1890.

„Gil-Blas”, 5.04.1885.

„Le Palais de justice. Journal Pittoresque des Tribunaux”, 25.02.1834.

Maupassant G. de, Bel-Ami, Paris 1910.

\section{Opracowania}

Balanda F.B. de, Louis de Bonald et la question du divorce de la rédaction du code civil à la loi du 8 mai 1816, „Histoire, économie \& société” 2017, n 3.

Bańczyk A., Literacki obraz przysięgi oczyszczajacej Izoldy a praktyka stosowania ordaliów $w$ średniowieczu, „Prace Naukowe Akademii im. Jana Długosza w Częstochowie. Studia Neofilologiczne” 2018, z. XIV.

Biet C., L'empire du droit, les jeux de la littérature, „Europe” 2002, 876.

Bismut R., Quelques problèmes de création littéraire dans "Bel-Ami », „Revue d'Histoire littéraire de la France" 1967, 67/3.

Bloom H., Guy de Maupassant, Philadelphia 2004.

\footnotetext{
${ }^{44}$ F. Terré, Préface [w:] Balzac. Romancier du droit, dir. N. Dissaux, Paris 2012, s. 26.
} 
Boninchi M., Vichy et l'ordre moral, Paris 2005.

Bruley Y., Mariage et famille sous Napoléon : le droit entre religion et laïcité, „Napoleonica. La Revue" 2012, nº 14.

Carbonnier J., Droit civil. Introduction, les personnes, La famille, l'enfant, le couple, Paris 2004.

Carnot J.-F.-C., Commentaire sur le code pénal : contenant : la manière d'en faire une juste application, l'indication des améliorations dont il est susceptible, et des dissertations sur les questions les plus importantes qui peuvent s'y rattacher, vol. 2, Bruxelles 1835.

Chabrier A., Les genres du prétoire : chronique judiciaire et littérature au XIXe siècle, https://tel.archives-ouvertes.fr/tel-00942986 (dostęp: 28.04.2021).

Desan S., Family on Trial in Revolutionary France, Berkeley 2004.

Durepaire A., Chronique de fait divers et grandes affaires judiciaires : des différents discours sur le désordre des conduites dans la Gazette des tribunaux à la fin $d u$ $X I X^{e}$ siècle, „Les cahiers du journalisme” 2007, 17.

Écrire le mariage en France au XIX $X^{e}$ siècle, dir. S. Gougelmann, A. Verjus, SaintÉtienne 2016.

Gleyzes Ch., La femme coupable. Petite histoire de l'épouse adultère au XIXe siècle, Paris 1994.

Hollender B.D., La notion de fait injurieux dans le divorce et la séparation de corps au XIXe siècle, „,Revue historique de droit français et étranger” 2012, 90/3.

Kalifa D., Karila-Cohen P., Le commissaire de police au XIXe siècle, Paris 2008.

Lévy-Vroelant C., Un espace ouvert : usages sociaux du logement en ville entre 1830 et 1880, „Recherches contemporaines” 1996, 3.

Philippe C., Maupassant précurseur du mariage moderne [w:] Droit des personnes et de la famille. Mélanges à la mémoire de Danièle Huet-Weiller, Strasbourg 1994.

Phillips R.G., Le divorce en France à la fin du XVIII e siècle, „Annales. Économies, Sociétés, Civilisations" 1979, 34/2.

Ringelheim J., Droit, contexte et changement social, „Revue interdisciplinaire d'études juridiques" 2013, 1/70.

Rosen L., Law as Culture. An Invitation, Princeton 2006.

Sardon J.P., L'évolution du divorce en France, „Population” 1996, 51e année, n³.

Terré F., Préface [w:] Balzac. Romancier du droit, dir. N. Dissaux, Paris 2012.

Thuillier G., Bureaucratie et bureaucrates en France au XIXe siècle, Genève 1980.

White N., French Divorce Fiction from the Revolution to the First World War, London-New York 2013. 